\title{
Foot arch condition in comparison with the muscular balance of lower limbs in children at school age of 6-14 years
}

\author{
Natalia Skowron', Roksana Malak', Ewa Mojs², Włodzimierz Samborski ${ }^{1}$ \\ ${ }^{1}$ Department of Rheumatology and Rehabilitation, Poznan University of Medical Sciences, Poland \\ 2 Department of Clinical Psychology, Poznan University of Medical Sciences, Poland
}

\begin{abstract}
Introduction. Foot arch condition plays an important role in correct setting of lower limbs joints, proper muscles tone and well-being [1]. More and more frequently foot arch deviations affect population of school age children $[2,3]$. It is based on anatomic knowledge that abnormal foot arch is strongly connected with the disturbed muscle tone of lower limb. The aim of the presented study is to evaluate the relation between the foot arch condition and muscular balance of the lower limbs.

Material and methods. Children were assessed using the Clarke's angle and indicatory muscles length tests including: quadratus lumborum muscle, hamstring muscle, thigh adductors, piriformis muscle.

Results. Abnormal foot arch was showed by $70 \%$ of subject children. The greatest number of muscles length abnormality was observed in quadratus lumborum muscles. There was a statistically significant correlation between right hamstring muscle contraction and abnormal foot arch $(p=0.011)$.

Conclusions. Foot arch alternations increasingly more often appear in the greater number of school-age children. The assessment and therapy of abnormal foot arch should include the examination of muscular balance of the lower limbs.
\end{abstract}

Keywords: children, flat foot, muscular length, hamstring muscle.

\section{Introduction}

The human foot is made up of 26 bones and above 30 articulations. It ensures supporting, shock absorbing and weight-bearing functions [4]. The proper human foot condition has been the center of interest of many researches [5].

Postural abnormalities more frequently affect children and youth at school age $[6,7,8]$. Foot arch defects are ones of the most recognizable postural deviation among children and adolescents $[2,3]$. They have differentiated etiologies and causes which are connected with school environment and behavioral habits [5, 9].

Low level of physical activity, leisure time spending passively, invalid nutritional habits, overweight and obesity result in body posture defects [10, 11]. Postural abnormalities are inseparably associated with the changes of muscles length and laxity [12]. The muscular imbalance affects foot arches and results in foot abnormalities, mainly flat foot [13-15]. It should be emphasized that flat foot is the physiological stage during the first decade of life and does not need treatment. It is visible when children begin standing and walking and disappears spontaneously [15]. However, the progress of untreated abnormal foot condition may result in structural changes in the skeletal system, incorrect setting of lower limbs joints and escalating pain [15]. That is why the foot posture should be examined by a specialist in order to exclude pathological conditions. 


\section{Aim}

The aim of the presented study is to evaluate the relation between the foot arch condition with muscular balance: the length of lower limbs indicatory muscles (quadratus lumborum muscle, hamstring muscle, thigh adductors, piriformis muscle) in children at the age between 6 and 14 years old from the primary school of the Mosina Community.

\section{Material and methods}

The study group consisted of 65 healthy school children (40 girls, 25 boys) attending the primary school in the area of the Mosina Community. The age of examined children ranged from 6 to 14 years and the average age was 9 years old and 4 months $=1$ years and 7 months. Participants were divided according to age range into 4 groups: < 6 years old (5 children), 7-10 years old (37 children), 11-12 years old (19 children), 13-14 years old (4 children) [16].

\section{Measurement}

The pedograph footprints were used to evaluate foot arch of children. They was obtained by placing the child's foot covered with footprint ink on the stretched paper. Based on the obtained footprint, Clarke's angle was calculated as foot arching parameter. Clarke's angle assesses the longitudinal foot arch and is widely used in screening examination [17, 18]. It was constructed by drawing the first medial tangential line of the footprint and the line connecting the first metatarsal head and the acme of the medial longitudinal arch cavity $[1,19]$.

The results of the Clarke's angle were recorded as "normal" (the Clarke's angle between $42^{\circ}-52^{\circ}$ ), "flattened" (the Clarke's angle between $31^{\circ}-41^{\circ}$ ) and "flat" (the Clarke's angle below $30^{\circ}$ ) [19]. All footprints were evaluated by the same person.

Muscles of the lower limbs were assessed with indicatory muscles length tests including: quadratus lumborum muscle, hamstring muscle, thigh adductors, piriformis muscle. The length of quadratus lumborum muscle was assessed while standing when the child slided his/her arm along the outer side of the thigh, without front or back bending. (Norm: The fingers of bending side reach the edge of the knee). Passive straight leg raise test was conducted to evaluate hamstring muscles (Norm: Hip flexion amounts to $80^{\circ}$ ) and Patrick's Test to evaluate tight adductors (Norm: The flexed knee reaches the level of the straight leg). Piriformis muscle was tested in pronation with flexed knees. The hips were laterally rotated. (Norm: Lateral rotation of hip amounts to $30^{\circ}$ ) [20].

\section{Protocol and data analysis}

Data were analyzed using Microsoft Excel by Microsoft Office 2007 and STATISTICA 8.1. Categorical variables were investigated using $\mathrm{Chi}^{2}$ Pearson Test and Test $\mathrm{Chi}^{2}$ Pearson Yates Test. Mann-Whitney $\mathrm{U}$ test was used for comparing two independent samples. The correlation coefficient was statistically significant when the $p$ value was less than 0.05

\section{Results}

Foot arch was assessed as normal in 30\% of children, flattened in $30 \%$ of children, flat in $40 \%$ of children

(Figure 1). In the group of boys flattened and flat foot

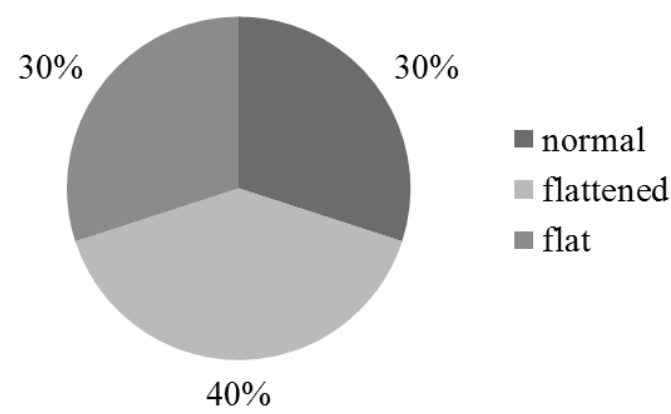

Figure 1. Results of the Clarke's angle

Table 1. The number of shortened indicatory muscles, including the right and left side

\begin{tabular}{cccccccccc}
\hline & \multicolumn{2}{c}{ Quadratus lumborum muscle } & \multicolumn{2}{c}{ Hamstring muscles } & \multicolumn{2}{c}{ Tight adductors } & \multicolumn{2}{c}{ Piriformis muscle } \\
\cline { 2 - 22 } & Left & Right & Left & Right & Left & Right & Left & Right \\
\hline The number of children & $38 \%$ & $29 \%$ & $28 \%$ & $31 \%$ & $14 \%$ & $9 \%$ & $6 \%$ & $11 \%$ \\
\hline
\end{tabular}

Table 2. The number of correct muscles length, including the right and left side

\begin{tabular}{ccccccccc}
\hline & \multicolumn{2}{c}{ Quadratus lumborum muscle } & \multicolumn{2}{c}{ Hamstring muscles } & \multicolumn{2}{c}{ Tight adductors } & \multicolumn{2}{c}{ Piriformis muscle } \\
\cline { 2 - 10 } & Left & Right & Left & Right & Left & Right & Left & Right \\
\hline The number of children & $62 \%$ & $71 \%$ & $72 \%$ & $69 \%$ & $86 \%$ & $91 \%$ & $94 \%$ & $89 \%$ \\
\hline
\end{tabular}


Table 3. The relationship between the results of the evaluation of lower limbs muscles tonicity and foot arch

\begin{tabular}{|c|c|c|c|c|c|c|c|c|}
\hline \multirow{3}{*}{ The number of children with abnormal foot arch } & \multicolumn{2}{|c|}{ Quadratus lumborum muscle } & \multicolumn{2}{|c|}{ Hamstring muscles } & \multicolumn{2}{|c|}{ Tight adductors } & \multicolumn{2}{|c|}{ Piriformis muscle } \\
\hline & Left & Right & Left & Right & Left & Right & Left & Right \\
\hline & 16 & 14 & 17 & 14 & 2 & 5 & 3 & 3 \\
\hline$p$ & NS* & NS* & NS* & $r^{* *}$ & $N S^{*}$ & NS* & NS* & $N S^{*}$ \\
\hline
\end{tabular}

was presented more often (84\%) than in the group of girls (63\%).

Tables 1 and 2 illustrate the results of muscle tonicity evaluation.

The measurement of muscles flexibility shows that quadratus lumborum muscles were the most often shortened muscles. In contrast piriformis muscles had the least often tendency to shorten.

\section{Relationship between foot arch and lower limbs muscles tonicity}

Comparative analyses were conducted between the results of indicatory muscles length tests (quadratus lumborum muscle, hamstring muscle, thigh adductors, piriformis muscle) and the results of Clarke Index. The obtained results are presented in Table 3.

There was a statistically significant correlation between right hamstring muscle contraction and abnormal foot arch $(p=0.011)$. However, there was no significant correlation between left hamstring muscle length and foot arch alterations ( $p=0.10796)$.

\section{Discussion}

In the past decade flat foot has been an object of many studies and it seems to be a very common postural problem in children [21, 22]. In the present study deviation of proper foot condition occurred in $70 \%$ of children. This is consistent with previously study of foot arches condition among children at school age $[23,24]$. In the study done by Janiszewska et al., foot arches malformation occurred in more than half of the children [25]. The significantly higher results obtained Brzeska et al, the frequency of flat foot was observed in $78.4 \%$ of the research group [26].

Flat foot was more frequent among the group of 7-10-year-old children in the presented research. Literature suggests that the majority of preschool children commonly present abnormality in foot arches [27, 28]. Different results in the presented study can result from very small number of children in the research group who were in preschool age. Walczak and Napiontek have suggested that the occurrence of abnormal foot arches condition among preschool children is connected with a layer of fat tissue covering foot arches which is physiological for this period of the ontogenesis [29]. The foot arches development change over time in close relation to ontogenesis [27]. It is noteworthy that the frequency of flat foot decreases in children over 10 years old. Similar observations were made by Kania - Gudzio and Wiernicka [30]. The age above 10 years refers to improvements in forming foot arches or development of increased foot arches during puberty. The foot spontaneously evolves to the proper physiological shape of the adult's foot at around 10 years of age [27]. In the study performed on the group of children from the Hausa ethnic group of Nigeria, Umar and Tafida diagnosed flatfoot significantly more often in the group of girls than in the group of boys [31]. Opposite to the research by Umar and Talida, in the presented study flatfoot was more common postural alteration among boys than girls. This is consistent with data published by other researchers [15, 32, 33]. The literature suggests that higher incidence of flat foot in boys may be results of the general process of foot morphology and development. The intensive period of the growth of boys feet begins later and last longer [34]. It occurs between 13 and 15 years of age [35].

There are a lot of factors contributing to the development of foot flat, such as BMI, gender, and age [36]. Only few authors take into consideration flat foot and muscular imbalance in their analyses [37, 38]. That is why the main aim of the presented study was to make comparative analysis of length of lower limbs muscles with foot arches condition. The presented study found that there was a significant correlation between right hamstring muscle contraction and abnormal flat foot. This is consistent with the other studies and anatomy of myofascial system [37-40]. There is exists skleletal-myofascial connection between two tapes of: the Spiral and the Lateral Tape, through two tendons: peroneus longus muscle tendon and peroneus brevis muscle tendon. The Spiral Tape passes under the foot arch, creating a loop (stirrup), which is a connection between tibialis anterior muscle and peroneus longus muscle. It joins the foot arch with upper part of a calf. 
Myofascial structures of peroneus longus muscle passes through external part of a shank to the caput fibulae, where there is located Connection between peroneus longus muscle with biceps femoris muscle (lateral side of hamstrings muscle group). There is a pronounced fascial connection between caput fibulae and peroneus longus muscle [39]. That is why there is a relationship between contraction of hamstring muscle and flat foot which was presented by Ippalito et al. [40]. They showed in Volumetric magnetic resonance imaging that postero-medial muscular compartments of the leg with flat foot are thinner and shorter than those of the normal leg [40].

It should be noted that, in the future untreated defects in foot arches condition such as flatfoot may play an important role in the development of pain and pathologic conditions of lower limbs $[1,15,21]$.

\section{Conclusions}

Based on the observation and analysis of the presented study we proposed the following conclusions:

1. Many children at school age suffer from foot arches defects.

2. The assessment and therapy of children with foot arch alterations should consider the examination of muscle tonicity of lower limbs.

\section{Acknowledgements}

\section{Conflict of interest statement}

The authors declare that there is no conflict of interest in the authorship or publication of contribution.

\section{Funding sources}

There are no sources of funding to declare.

\section{References}

1. Kasperczyk T. Wady postawy ciała. 4th end. Krakow, Wydawnictwo "Kasper" s.c. 2004.

2. La France M. Postural mirroring and intergroup relations. Pers Soc Psychol Bull. June 1985;2(1,1):207-217. 10.1177/0146167285112008.

3. Bart O, Hajami D, Bar-Haim Y. Predicting school adjustment from motor abilities in kindergarten. Infant and Child Development. November/December 2007;16(6): 597-615. 10.1002/icd.514.

4. Bochenek A, Reicher M. Anatomia człowieka Tom IV. Warszawa, Wydawnictwo Lekarskie PZWL; 1998.

5. Woźniacka R, Bac A, Matusik S, Szczygieł E, Ciszek E. Body weight and the medial longitudinal foot arch: high-arched foot, a hidden problem? Eur J Pediatr. 2013; 172:683-691. 10.1007/s00431-013-1943-5.

6. Hae-Chan P, Yang-Soo K, Sang-Hun S, Soo-Kyung L. The effect of complex training on the children with all of the deformities including forward head, rounded shoulder posture, and lumbar lordosis. J Exerc Rehabil. 2014 Jun 30;10(3):172-175; 10.12965/jer.140113. eCollection 2014.

7. Mrozowiak M. Poziom i rodzaj zaburzeń postawy ciała w Polsce w latach 2004-2006. http://wadypostawy. republika.pl/publikacje6.htm.

8. Permoda A, Permoda A, Chudak B. The problem of occurrence of faulty postures in children and adolescents in the city of Zielona Góra and the region. Zdr Publ 2010; 120(4):361-364.

9. Homayouni K, Karimian H, Naseri M, Mohasel N. Prevalence of Flexible Flatfoot Among School-Age Girls. Shiraz E-Med J. 2015 February;16(2):e18005.

10. Kratěnová J, Žejglicová K, Marek Malý M, Filipová V. Prevalence and Risk Factors of Poor Posture in School Children in the Czech Republic. J Sch Health. 2007 Mar; 77(3):131-137. 10.1111/j.1746-1561.2007.00182.x

11. Gollenberg AL, Addo OY, Zhang Z, Hediger ML, Himes $\mathrm{JH}$, Lee PA. In utero Exposure to Cigarette Smoking, Environmental Tobacco Smoke and Reproductive Hormones in US Girls Approaching Puberty. Horm Res Paediatr. 2015;83(1):10.1159/000369168. Epub 2015 Jan 24.

12. Tomaszewska A, Pawlicka-Lisowska A. Evaluation of an influence of systematic motor activity on the body posture of young people. Pol Merkur Lekarski. 2014 May; 36(215):336-40. 24964512.

13. Feigenbaum LA, Roach KE, Kaplan LD, Lesniak B, Cunningham $\mathrm{S}$. The association of foot arch posture and prior history of shoulder or elbow surgery in elite-level baseball pitchers. J Orthop Sports Phys Ther. 2013 Nov; 43(11):814-820. 10.2519/jospt.2013.4504. Epub 2013 Sep 9.

14. Pauk J, Ezerskiy V, Raso JV, Rogalski MJ. Epidemiologic factors affecting plantar arch development in children with flat feet. J Am Podiatr Med Assoc. 2012 Mar-Apr; 102(2):114-121. 10.7547/1020114.

15. Pfeiffer M, Kotz R, Ledl T, Hauser G. Prevalence of Flat Foot in Preschool-Aged Children. PEDIATRICS 2006 August 1;2:63-639. 10.1542/peds.2005-2126.

16. Obuchowicz A. Badanie podmiotowe i przedmiotowe w pediatrii. Warszawa, Wydawnictwo Lekarskie PZWL; 2010.

17. Villarroya MA, Manuel Esquivel J, Tomás C, Buenafé A, Moreno L. Foot structure in overweight and obese children. Int J Pediatr Obes. 2008;3(1):39-45. 10.1080/17477160701520298.

18. Villarroya MA, Esquivel JM, Tomás C, Moreno LA, Buenafé $A$, Bueno $G$. Assessment of the medial longitudinal arch in children and adolescents with obesity: footprints and radiographic study. Eur J Pediatr. 2009 May;168(5):559-67. 10.1007/s00431-008-0789-8. Epub 2008 Aug 27.

19. Chen KC, Yeh CJ, Kuo JF, Hsieh CL, Yang SF, Wang $\mathrm{CH}$. Footprint analysis of flatfoot in preschool-aged children. Eur J Pediatr. 2011;170(5):611-7. 10.1007/s00431010-1330-4.

20. Buckup K. Clinical Tests for the Musculoskeletal System: Examinations - Signs - Phenomena. 2dn edt. Thieme Medical Publishers; 2008.

21. El O, Akcali O, Kosay E, Kaner B, Arslan Y, Sagol E, Soylev $S$, lyidogan $D$, Cinar N, Peker O. Flexible flatfoot and related factors in primary school children: a report of a screening study. Rheumatol Int. 2006;26:1050-1053. 
22. Chen JP, Chung MJ, Wang MJ. Flatfoot prevalence and foot dimensions of 5 to 13 year old children in Taiwan. Foot Ankle Int. 2009;30(4):326-332.

23. Forriol F, Pascual J. Footprint analysis between three and seventeen years of age. Foot Ankle.1990;11(2):101-104. 10.1177/107110079001100208.

24. Mickle KJ, Steele JR. The feet of overweight and obese young children: Are they flat or fat? Obesity 2006 Nov; 14:1949-53.

25. Brzeska P, Sokołowska E, Baumgart M. Zmiany postawy ciała u dzieci w wieku przedszkolnym w ciągu roku. Zeszyty naukowe Uniwersytetu Szczecińskiego Nr 771, Prace Instytutu Kultury Fizycznej Nr 28; 2012:205-213.

26. Janiszewska R, Tuzinek S, Nowak S, Biniaszewski T, Ratyńska A. Nieprawidłowości postawy ciała u dzieci 6-12 letnich - uczniów szkół podstawowych z Radomian badania pilotażowe. Probl Hig Epidemiol. 2009,90(3): 342-346.

27. Harris EJ. The natural history and pathophysiology of flexible flatfoot. Clin Pod Med Surg. 2010;27:1-23. 10.1016/j.cpm.2009.09.002.

28. Stavlas P, Grivas TB, Constantinos M, Vasiliadis E, Polyzois $V$. The evaluation of foot morphology in children between 6 and 17 years of age: a cross-sectional study based on footprints in a Mediterranean population. J Foot Ankle Surg. 2005;44(6):424-428.

29. Walczak M, Napiontek M. Stopa płaska statyczna dziecięca - kontrowersyjny temat. Chirurgia Narządów Ruchu i Ortopedia Polska. 2003;68(4):261-267.

30. Kania-Gudzio T, Wernicka M. Ocena postawy ciała dzieci w wieku 7 - 15 lat na podstawie wybranej losowo szkoły z miasta Poznania. Nowiny Lekarskie. 2002;71(2-3): 151-159.

31. Umar MB, Tafida RU. Prevalence of flatfoot and anthropometric comparison between flat and normal feet in the Hausa ethnic group of Nigeria. J Am Podiatr Med Assoc. 2013 Sep-Oct;103(5):369-373. 10.7547/1030369.

32. Staheli LT, Chew DE, Corbett M. The longitudinal arch. A survey of eight hundred and eighty-two feet in normal children and adults. J Bone Jt Surg Am. 1987;69: 426-428.

33. Garcia-Rodriguez A et al. Flexible fiat foot in children: a real problem? Pediatrics, 1999;6:1-3.
34. Bernhardt DB. Prenatal and postnatal growth and development of the foot and ankle. Phys Ther. 1988 Dec; 68(12):1831-9. 10.7547/87507315-85-12-753.

35. Volpon JB. Footprint analysis during the growth period. J. Pediatr. Orthop. 1994;14:83-85.

36. Chang JH, Wang SH, Kuo CL, Shen HC, Hong YW, Lin LC. Prevalence of flexible flatfoot in Taiwanese school-aged children in relation to obesity, gender, and age. Eur J Pediatr. 2010;169:447-452.

37. Pita-Fernández S, González-Martín C, Seoane-Pillado T, López-Calviño B, Pértega-Díaz S, Gil-Guillén V. Validity of footprint analysis to determine flatfoot using clinical diagnosis as the gold standard in a random sample aged 40 years and older. J Epidemiol. 2015;25(2):14854. 10.2188/jea.JE20140082. Epub 2014 Nov 8.

38. Moon DK, Gurnett CA, Aferol H, Siegel MJ, Commean PK, Dobbs MB. Soft-Tissue Abnormalities Associated with Treatment-Resistant and Treatment-Responsive Clubfoot: Findings of MRI Analysis. J Bone Joint Surg Am. 2014 Aug 6;96(15):1249-1256.

39. Thomas W. Myers Anatomy Trains. Myofascial Meridians for Manual and Movement Therapists. 2nd edt. Churchil Livingstone, Elsevier. 2009.

40. Ippolito E, Dragoni M, Antonicoli M, Farsetti P, Simonetti $G$, Masala S. An MRI volumetric study for leg muscles in congenital clubfoot. J Child Orthop. 2012 Oct;6(5):433-8. 10.1007/s11832-012-0444-9. Epub 2012 Oct 5.

Acceptance for editing: 2015-04-29 Acceptance for publication: 2015-05-28

Correspondence address: Natalia Skowron Department of Rheumatology and Rehabilitation Poznan University of Medical Sciences 135/147, 28 Czerwca 1956 Street 61-545 Poznan, Poland phone: +48695175684 e-mail: natalia.skw@vp.pl 